\title{
POWERS OF OBSERVATION
}

\author{
How to be a scientist.
}

\section{BY BETH CATO}

$\mathrm{I}$ 've been super-still in a tree for hours as I practise observation. I'm going to be a scientist, so learning to observe is very important. My corder hangs from my neck but I keep a hand near it all the time in case I spy something new. I already saw lots of birds that I mapped ages ago.

I'm about to climb down when I see a pretty red bird with white and black on its wings. I don't know the name, but I know it's in the RARE category for my region.

I snap a picture with my corder and hold my breath. A second later, the confirmation window pops up - the corder recognized the bird! Lots of words scroll by, but I can't read most of them. Letters look mixed up to me, like alphabet pasta dumped in a bowl.

As I climb down the tree, the corder makes a soft click. I glance at it once I'm on the ground. The screen has lots of balloons and a big word with a C. I gasp.

I know that this means I did something good, but I need Mom to read it for me.

I hurry home, still moving quiet like I've practised. My dog Mickey doesn't even wake up in the yard. I slip inside and follow Mom's voice to the kitchen. She's on the phone. Is she talking to Dad? He's down in Bothell, where people make parts for the big spaceships.

Mom looks angry like I've never seen her before. I crouch down behind the table and watch her through a gap in the chairs.

"I sent you the info on my son Luis last week. I never heard back. I need him on the list." Mom growls. "Don't give me that. I don't believe any of that 'fair and unbiased' lottery garbage."

Luis is me. Why's she talking about the lottery, though? It is fair. All the ads and posters say so. They show whole families that are sad but hopeful as they wave bye-bye to Earth and leave before the rocks fall from outer space.

“My husband and I ... we don't have essential skills to pri- $\rightarrow$ NATURE.COM

Follow Futures:

@ @NatureFutures

f go.nature.com $/ \mathrm{mtoodm}$ oritize us for spots. I know rich families are paying their way in. Your quote to get three people aboard is ...? Yeah. We ... can't do that. I expected as much." She takes in big, deep breaths. "But Luis needs a berth. I was told you could make this happen. He's healthy, smart. He's dyslexic, yes, but with help..."

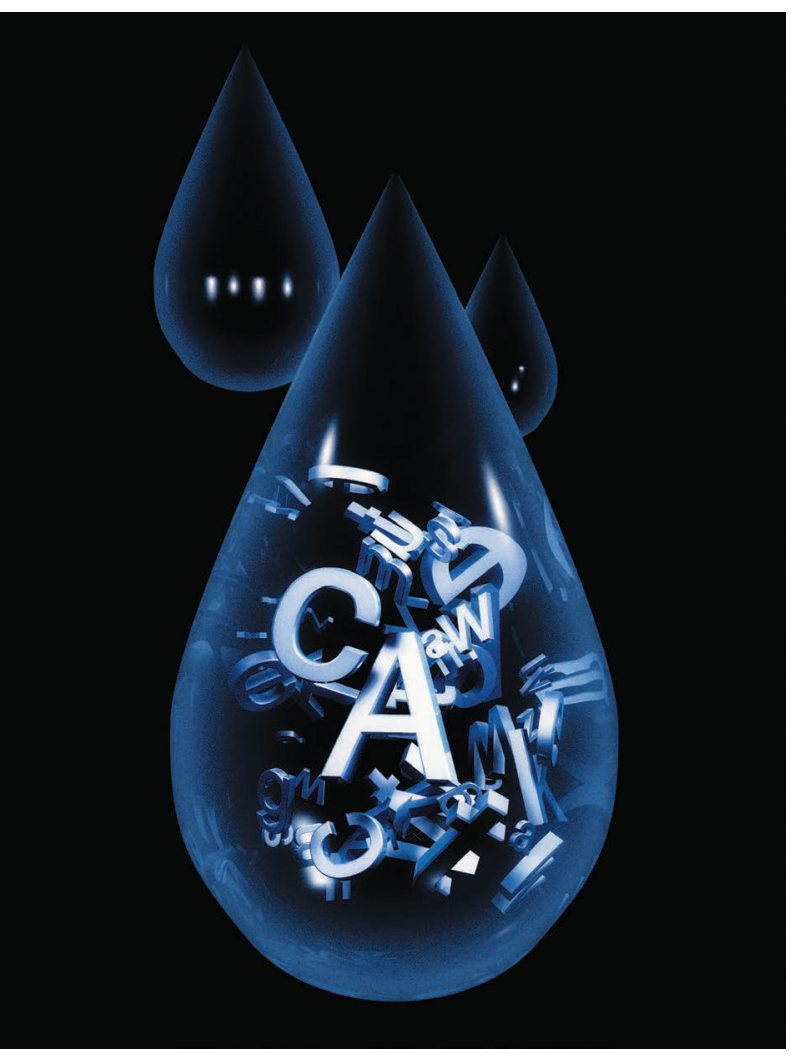

The expression on her face scares me. Her free hand clenches her cross pendant like she could squeeze it flat. She's silent for a minute. "Really? I want information on this couple, that they really want to adopt and love a child. That they understand this is forever."

What is she talking about?

She goes quiet again. "Yes. I can send you the first payment in a few minutes." She sets up her tablet on the counter. Her legs are quivering like she's cold. Out in the yard, Mickey starts to bark. "I have to go. I think Luis is coming home for lunch. I'll hear from you within three days with that information, then? Thank you."

I figure I should act like I just came in. I scoot back to the front door, and open and shut it, loud this time.

"Hi, Mom!" I say as I walk into the kitchen. "Look!" I thrust the corder in her face. She doesn't look angry now, but really happy to see me. Her tablet is face-down on the counter.

"Wow." She reads my corder's screen. "Congratulations, you're now one of the top 50 bird mappers for the whole state, and number one for our county. I'm proud, mijo." She hands back my corder. "You're doing better than most grown-ups."

"I'm saving all the birds!"

"Yes, you are. A number of these birds haven't had their DNA sequenced yet. They'll send a 'bot soon to get that done. You can map other creatures, too, remember. The New Earth scientists need to know all about bugs and mice and other things to preserve their data on the ships."

"I can do that." I puff out my chest. "Being champion mapper will make me look extra good in the lottery!"

Soon as I say that, I think, maybe I shouldn't have. She might realize I was listening in and I'll be in big trouble. But she only leans in to give me a quick kiss on the forehead.

"Don't you worry about the lottery, Luis. We'll take care of you, however we can." She blinks fast. "Go wash your hands. I'll heat up lunch."

"Macaroni and cheese?" I back away.

"Macaroni and cheese." Her smile seems stiff and weird, like how she looked last week when her cheeks were numb after the dentist took the gold out of her teeth.

I get to the hallway and take off my shoes and go ninja-quiet again. Instead of going to the bathroom, I sneak to the dining room.

Mom is staring at her tablet and she's crying so hard she might fall down. Her hand hovers like she can't quite touch the screen. "Luis will live. That's what matters," she says over and over.

Of course I'll live! I frown, confused. She should be happy I'm such a great mapper, and that we're going to have mac and cheese. Instead, she sobs.

I continue to observe her, because that's what scientists do. I want to understand why she's so sad. Maybe then, I'll know how to make her happy again.

Beth Cato resides in Arizona. Her novel Breath of Earth begins a new alternate history series with Harper Voyager. Her website is BethCato.com. 